\title{
Role of School: Habitus and Policies Towards Character Education
}

\author{
Hidar Amaruddin ${ }^{1}$, Muhammad Khafid ${ }^{2}$, Hamdan Tri Atmaja ${ }^{2}$ \\ \{Hidars46@gmail.com¹: muh_khafid@mail.unnes.ac.id²; hamdanta@mail.unnes.ac.id $\left.{ }^{3-}\right\}$ \\ Graduate School, Universitas Negeri Semarang ${ }^{1,2,3}$
}

\begin{abstract}
The background that underlies this research is the disappearance of the politeness character values of fifth grade elementary school students. The purpose of this study is to find out and prove the habitus theory and the role of the school in the character of politeness of fifth grade elementary school students. The results of this study are categorizing and classifying the school's role towards the character of the fifth grade elementary school students, that the school has three roles: educating, teaching knowledge, and evaluating. Conclusions in this study are on the role of educating, the school has the authority to form character by making policies or regulations made, and the learning process carried out by teachers and principals. Teaching knowledge that has the character of strengthening education in each device and learning process, and evaluating cognitive, psychomotor and affective aspects (attitudes and behaviors) of students by planting politeness character values that are done with habituation and continuous.
\end{abstract}

Keywords: Role, School, Character, Politeness, Case Study

\section{Introduction}

Presidential Regulation number 87 of 2017 in Indonesia, concerning strengthening character education. It is intended that character education aims to protect the nation's children, and develop noble character values that exist in children[1]. The implementation of noble character is needed to shape and develop character in children, so that it is not only successful in the cognitive field, but also good in attitude and behavior.

Theory of study, that there are three educational pillars that shape children's character, namely: family, school, and environment[2]. Education at the school level has a role in delivering and guiding and directing children to achieve educational goals, but not apart from the efforts of teachers who have accepted the responsibilities of the family of children. So the task of the teacher besides providing knowledge, skills also educates religious children and noble character.

In the 2013 curriculum the 2018 revision indeed always emphasizes and strives that there is always a charge of character values in each learning. The character values are divided into fifteen character values which are summarized into five broad outlines of character values, namely: religious, nationalist, integrity, independence, and mutual cooperation. The character value is implemented in stages, systematically, and culturally. Permendikbud no.22 of 2016 
concerning process standards, outlining core competencies, including: spiritual, social, knowledge, and skills. The character of politeness is included in the second competency which is about social attitudes that must be possessed by a child[3].

However, there are still some cases that conflict with the values of noble characters. For example, the irreverent actions taken by students to teachers, teachers who were instructed by the students themselves only because they gave a reprimand, and persecuted their guardians towards the teacher because they did not accept their children being reprimanded. And what is still inherent in the memory is a teacher who died because of being persecuted by his own students[4].

Moral character or politeness values can be taught to students in schools by establishing noble cultural habits. Although it seems simple, implicitly the character value will be embedded in students' thinking. Some of the values of social life such as culture and morality are becoming a holistic and thematic unit because they are interrelated in shaping the character of students[5].

The school environment the most significant influence on the behavior or attitudes of children is the teacher as an educator. The teacher in his position as spiritual father for students, who provides food for soul and knowledge, moral formation, and rectifies bad or negative behavior. Salaby in his book "history of Islamic education" said the character of children as students to educators (teachers) should be inferior, respect and memuliaka the teacher, and obey his advice[6].

The purpose of this study was to categorize the roles of schools in the classroom and outside the classroom from those who have authority and roles in the school: teachers and principals towards the character of the politeness of fifth grade students at the Primadana and Supriyadi elementary schools in Semarang. And the theoretical benefits of this research are to prove or refute the theory of habitus from Pieere Bourdieu.

\section{Methods}

The method in this study uses qualitative descriptive approach. Using case study techniques in fifth grade students at Primadana Elementary School and Supriyadi Elementary School Semarang.

Data collection techniques used in-depth interviews with fifth grade teachers from both schools, and two principals. Then observation data to see the character of politeness in students.

\section{Results and Discussion}

The school's role in the character of the politeness of fifth grade elementary school students is carried out in two primary schools, namely the Supriyadi elementary school and the 
Primadana elementary school. School is the second place or environment after the family. Schools become places or habitats that can influence children's attitudes and behavior.

Habitus theory from Bordieu, explains that, habitus becomes the basis of action and mindset that combines disposition as a tendency to behave and order generative classification as the principle of judgment. Habitus will produce results, namely, differences in lifestyle or practices of life, according to experience (empirical) and the process of internalization of agents (communities) in interacting with other agents, as well as objective structures in which individuals are located[7]. So the school provides empiricism and the process of internalizing the community.

Institution certainly needs an organization to be better coordinated, this is to facilitate the institution in carrying out the agreed-upon plans. The principal is responsible for activities, assisted by the school development team and coordinators. The coordinator is student coordinator, coordinator of facilities and infrastructure, coordinator of school relations with the community, and others. As for the elaboration of the management of character education reinforcement programs are as follows: (1) the principal, as the person in charge of activities, and school policies, (2) the school development team, which consists of curriculum coordinators and school quality developers, namely assisting school principals in supervising, making work programs, and helping the program run, (3) school coordinators, helping the school development team[8].

Character education is important for human life, then the role played by the world of education should not be to merely provide moral knowledge, as well as ways of loving and willing to take moral actions[9]. The similarity between the research conducted by Sudrajat and this research is within the scope of character education.

That observations and interviews at Muhammadiyah (Plus) Elementary School in Salatiga showed that the character education of cooperation, empathy, and culture of community-based schools had gone well at a maximum calculated level ranging from $95 \%$ to $97 \%$. The expected condition occurs in Salatiga, not necessarily in Semarang[10], it will also get the same results in the implementation of character education for its impact on students, especially focusing on moral character, namely politeness.

Based on qualitative case study research carried out on several information, among others: two principals and two classroom teachers, produced descriptive research data, which categorized the role of schools in politeness character values as follows:

\subsection{Educate}

Outside The Classroom. In the role of educating schools divided into two, namely in the class that has the authority is the teacher. And outside the class that has the authority is the principal.Based on in-depth interviews with two school principals Supriyadi and Primadana, explained that the two schools emphasized several policies that were different from other schools. Namely: the implementation of religious education through school culture. The activity was in the form of prayers in congregation at the school mosque when the midday 
prayer and asr prayer. All students from grades three to six of elementary school must attend. While the low class from grade one to two only attend the congregational prayers.

In the classroom. Teachers in educating have a basis that should not be abandoned. Namely the implementation of religious values. And provide examples of practical politeness. Which is taught in an integrated manner through thematic learning. In addition to teaching cognitive theory, also the formation of attitudes and behaviors can grow from the stories of goodness conveyed by the teacher by adjusting to the learning material. School as an oasis is a vehicle to gain knowledge and personality development. At school, children try to interact with the teacher, and carry out the process of respecting and obeying the rules. Schools must also help students understand the values of character education. adopt or practice it for children, and act in their own lives. Moral education not only prioritizes cognitive aspects or intellectual abilities, it also requires emotional / spiritual dimensions that serve as a bridge between assessment and action. The emotional / spiritual side includes at least the qualities of conscience, self-esteem, empathy, love, self-control and humility[11].

\subsection{Teaching Knowledge}

The teacher is tasked with teaching knowledge comprehensively and holistically. Where do not differentiate students from one another. Have certain ways to deal with the level of student understanding of the material. Learning innovation is done in making learning devices (RPP), so that the character of politeness can be contained integratively in each learning process.

\subsection{Evaluate}

The most fundamental task is to evaluate. Evaluate cognitive, affective, and psychomotor. In the character of politeness, a teacher must focus on monitoring and evaluating student attitudes and behavior. By: giving a warning, giving a warning, and the last step is to invite parents to discuss the attitudes and behavior of students, if the previous two steps have been passed but without results.

According to Bourdieu the form of 'hexis-habitus' is influenced by, places in the individual body, forms of perception, representation and thought, as well as forms of world social evaluation and evaluation, which function as generative and organizing principles that tend to define agent practices. In practice according to Bourdieu, about the relationship with hexis-habitus, and the interpretation of individual practices can only exist through connections that are hexis-habitus effects, and also influenced through practice[12]. This connection can be found in the two conditions of the social world, in the first concerning the objective social conditions of the existence of agents where hexis-habitus, which produces practice, is formed, and the second concerns the social conditions in which hexis habitus is placed and functioning.

So the behavior and character inherent in the child is formed because of the environment he is facing. Where he obtained education, therefore the role of the school greatly determines 
the character of the child. How the child's attitude and behavior depends on the role of the surrounding environment. And the behavior possessed by children is the result of internalizing themselves in the environment and agents (other people who influence). However, the lifestyle / behavior produced by the habitus scheme is not absolute. Because the habitus scheme in the evaluation phase, provides an opportunity for individuals to remain or change their behavior.

The early stages of the implementation of character education at the school level there needs to be syntagmatic through moral conditioning which then continues with moral training. Character education like this functions as a systemic vehicle for developing moral character that equips students with moral intelligence competencies[13].

The school correlation as habitat proves Pierre Bourdieu's theory of habitus and categorizes the role of the school namely: the policy, vision and culture of educating, teaching knowledge, and evaluating students conducted by the school determines how students' attitudes and behavior, especially in politeness. The character of politeness is taught by the school in simple and continuous ways. For example: bending when walking in front of a teacher, kissing the teacher's hand, not saying dirty words. If by cultivating this attitude of politeness, implicitly the character of politeness will be embedded in students.

\section{Conclusion.}

The conclusions obtained in this study are, the role of schools is divided into several indicators, among others: the principal as head of the institution of a school institution has important authority in making policy and vision and mission to support the character of politeness to become a daily culture in school. The teacher has three roles, namely: educating, teaching knowledge, and evaluating. The three role indicators are interrelated. The earliest education is to instill religious values as a basis, to lead to the formation of attitudes, behaviors, socialization of students that reflect the character of politeness. This research is useful for the school in making policies, compiling learning tools, studying the learning process that aims to shape the character of student politeness. The researcher hopes that other academics will take part in reviewing and developing research on the role of schools in the character values of politeness in fifth grade elementary school students in a wider scope. 


\section{References}

[1] Peraturan Presiden Republik Indonesia.: Undang-undang No. 87 Tahun 2017 tentang Penguatan Pendidikan Karakter. Lembaran RI Tahun 2017 No.195. Jakarta: Sekretariat Negara (2017)

[2] Indra, Machful K.: "Tri Pusat Pendidikan Sebagai Sarana Pendidikan Karakter Anak Sekolah Dasar". Jurnal Pedagogia. 4(1). pp. 41-49 (2015)

[3] Permendikbud.: Peraturan Menteri Pendidikan dan Kebudayaan No. 22 Tahun 2016 tentang Standar Proses Pendidikan Dasar dan Menengah. Lembaran RI Tahun 2016. Jakarta: Kementrian Pendidikan dan Kebudayaan (2016)

[4] Taufiqurrahman, Kompas. (2018). Guru SMA di Sampang Meninggal Dianiaya Siswanya, Kini Pelaku Diamankan Polisi, accesed from https://regional.kompas.com/read/2018/02/02/11344891/guru-sma-di-sampangmeninggal-dianiaya-siswanya-kini-pelaku-diamankan-polisi, 26th December 2018.

[5] Sri, S.: "Muatan Pendidikan Karakter Pada Pembelajaran Ilmu Pengetahuan Sosial Di Sekolah Dasar". Jurnal Sekolah Dasar. 21(2). pp: 118-124 (2012)

[6] Lahmi, Ahmad.: "Peranan Sekolah Dalam Pendidikan Islam". ISTAWA: Jurnal Pendidikan Islam. 1(2). pp. 121-138 (2016)

[7] Yudha, Kukara K.: "Paradigma Teori Arena Produksi Kultural Sastra: Kajian Terhadap Pemikiran Pierre Bourdieu". Jurnal Poetika. 1(1). pp: 3-15 (2013)

[8] Maisaro, Atik, Bambang Budi Wiyono \& Imron Arifin.: "Manajemen Program Penguatan Pendidikan Karakter Di Sekolah Dasar". Jurnal Administrasi dan Manajemen Pendidikan. 1(3). pp. 302-312 (2018)

[9] Sudrajat, A.: "Mengapa Pendidikan Karakter?". Jurnal Pendidikan Karakter. 1 (1). pp. 47-58 (2011)

[10] Azhari, Eko Handoyo \& Mukhammad Khafid.: "The Implementation of Integrated Character Education in Policy Design at SD Muhammadiyah (Plus) Salatiga". Journal of Primary Education. 7(2). pp.. 172-178 (2018)

[11] Nasiruddin.: "Peran Keluarga, Sekolah, Dan Masyarakat Dalam Pendidikan Karakter Generasi Muda Bangsa". Prosiding Seminar Nasional Tahunan Fakultas Ilmu Sosial Universitas Negeri Medan. 1(1). pp. 339-343 (2017)

[12] Asimaki, Anna \& Gerasimos Koustourakis. "Habitus: An attempt at a thorough analysis of a controversial concept in Pierre Bourdieu's theory of practice". Social Sciences: Science Publishing Group. 3(4). pp. 121-131 (2014)

[13] Setiawan, D. "Peran Pendidikan Karakter Dalam Mengembangkan Kecerdasan Moral". Jurnal Pendidikan Karakter. 3(1). pp. 53-63 (2013) 